International Journal of Instruction e-ISSN: 1308-1470 • www.e-iji.net

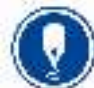

July $2021 \bullet$ Vol.14, No.3

p-ISSN: 1694-609X

pp. 661-684

Article submission code:

20200528190317

Received: 28/05/2020

Revision: 13/01/2021

Accepted: 07/02/2021

OnlineFirst: 10/06/2021

\title{
A Mixed-Methods Study of the Future Qualifications of English Teachers in the South of Thailand
}

Orada Opasrattanakorn

Language Institute, Thammasart University, Thailand, prettyorada@gmail.com

Kittitouch Soontornwipast

Ed.D., Language Institute, Thammasart University, Thailand, tranraja@gmail.com

$\mid$

This mixed-methods study aimed to explore the expected qualifications of English teachers in the South of Thailand. The Delphi technique and exploratory sequential design were employed with three phrases of study: a qualitative and two quantitative phases. For the qualitative phase, 49 experts who were from professional organization, educators and school teachers responded to an openended questionnaire and semi-structured interview asking their opinions toward the expected qualifications of English teachers in the South of Thailand in the next five to ten years. The data from the open-ended questionnaire and interview were analyzed by using content analysis. 216 qualifications emerged from the qualitative data were developed into a rating scale questionnaire that was sent back to the same experts to confirm each qualification. The finding revealed that 197 qualifications were kept and 7 were deleted. The 12 qualifications that needed reassessment were sent back to the same experts. The result indicated that 6 of them were kept. The final 203 qualifications were proposed. These qualifications could be

Keywords: delphi technique, English teacher education, exploratory sequential design, mixed methods study, qualifications of English teachers

\section{INTRODUCTION}

Nowadays, English in Thailand has become essential for diplomacy, science, aviation, economy, tourism, education and etc. According to the latest EF English Proficiency Index (EF EPI), however, Thailand has been classified in the 'very low proficiency' group with a ranking of 74th out of 100 countries (Education First, 2019). Undoubtedly, Thailand's low English proficiency level has become a highly controversial topic and considered as an indicator in English language teaching failure. So, English teacher education seems to have a role to play.

With the advent of Thai Qualifications Framework for Higher Education (TQF: HE), core competencies of teacher education programs have been developed and proposed as a national framework for teacher education programs development (Minister of

Citation: Opasrattanakorn, O., \& Soontornwipast, K. (2021). A mixed-methods study of the future qualifications of English teachers in the south of Thailand. International Journal of Instruction, 14(3), 661-684. https://doi.org/10.29333/iji.2021.14339a 
Education, 2009). Because the suggested guidelines are highly top-down developed by scholars from the central area selected by the Office of Higher Education (OHE), unique and different characteristics for each local teacher education institute area are not taken into consideration.

Following the 'one-size-fits-all' guidelines of TQF strictly, none of the English teacher curriculum can be outstanding, up-to-date or unique. The TQF provides guidelines for all aspects needed in English teacher curriculums by specifying objectives, program management, content knowledge, learning outcomes, assessment and evaluation. No specific qualifications of English teachers have been included. Additionally, while the government put great emphasis on developing teacher education to meet international standards, Thai uniqueness was faded away. Also, Zeichner (2006, as cited in Wattanatorn, 2013) also stated that knowledge about ethnic groups and local cultures need to be incorporated in teacher education programs. In Thailand, eighteen regional education offices have been established countrywide to organize education effectively. Each region is unique and different in terms of economy, social conditions, religions and cultures.

Overall, the south of Thailand covers both main land and islands with a wide diversity of religions, languages, lifestyles, careers, cultures and incomes. Being responsible for one of the English teacher education programs, the researcher found that existing curriculums preparing English teachers in the South have been shaped as one-size-fit-all curriculums. This top-down technique does not work well for producing English teachers in the South. With twenty-two-years teaching experience and being a southerner, the researcher think that English teachers in the South should possess specific qualifications suitable for the southern context of economy, society, cultures and religions. However, expected qualifications for English teachers in the South have not been officially studied.

In line with the curriculum development innovation, the analysis of student teachers' pre-specified outcomes, or knowledge and skills acquired from a teacher education program, is considered as the basic assumption of curriculum development in educational system (Richards, 2001). Having students' ultimate outcomes as guidelines for model or curriculum development offers curriculum developers the flexibility to organize both learning experiences and instruments used to evaluate students' progress. In addition, the clear specification of desired outcomes can promote not only the quality of assessment, but also the quality of teaching and student learning (Docking, 1994 as cited in Richards, 2013).

A wide range of studies exploring the qualifications of effective English teachers have been reported. However, most studies were conducted with undergraduate students, university educators and novice teachers. Furthermore, the qualifications found from the previous studies were not particular for the context of the southern part of Thailand. In order to identify the qualifications of English teachers in the South of Thailand, the researcher has made decision to study the opinions of experts. Thus, the Delphi technique has been the most appropriate data collecting method since it is the method collecting data from various groups of experts and suitable for future tendency studies. 
According to Linstone and Turnoff (1975), the Delphi technique had practical use in educational setting, especially forecasting future tendencies. Furthermore, Green (2014) also confirmed the use of Delphi in forming guidelines, standards, developing curriculums, learning experiences to prepare students for future careers, and predicting trends in educational settings.

Significantly, studies using the Delphi to explore the qualifications of English language teachers as pre-specified outcomes of English teacher education model or curriculum development have been rarely conducted in Thailand. Additionally, an exploratory sequential design (Creswell \& Plano Clark, 2011) was also implemented with the Delphi technique.

This investigation of the expected qualifications of English teachers in the South of Thailand is an initial part of the research project entitled "The development of English teacher education model in the South of Thailand". It aimed to answer the research question: What are the expected qualifications of English language teachers in the South of Thailand?

\section{Review of Literature}

\section{Qualifications of Effective English Language Teachers}

A good language teacher is assumed to have a number of qualifications (Brosh, 1996; Brown, 2001). The qualifications of effective English teachers have been reported in many studies. Some characteristics of effective English teachers have been universal, especially English proficiency, pedagogical knowledge, and socio-effective skills (Park \& Lee, 2006). Interestingly, Park and Lee's framework has been applied in many later studies (Wichadee 2010; Wichadee \& Orawiwatnakul, 2012; Zamani \& Ahangari, 2016) with an additional domain, organization and communication skills. However, the qualities of English teachers were varied.

The study of Wichadee (2010) showed that organization and communication skills were important in the students' points of view but the teachers highlighted on English proficiency. Effective English teachers were best described in terms of organization and communication skills and socio-effective skills (Wichadee \& Orawiwatnakul, 2012). Socio-effective skills were concluded as the most important aspects, especially developing proper relationship with students and building students' confidence in Zamani and Ahangari (2016). Moreover, Mahmoud and Thabet (2012) conducted their study based on the same dimensions employed in Wichadee \& Orawiwatnakul (2012) and suggested some specific qualities of English teachers, emphasizing on a high level of English language competence and fluency and the involvement of students in classroom activities.

Barnes and Lock (2013) explored 5 categories, including rapport, delivery, fairness, knowledge and creditability, organization and preparation. 3 most important aspects, namely delivery, knowledge and creditability, rapport, were reported.

Celik et al. (2013) studied 3 groups of characteristics with 2 aspects under each category, namely personal qualities and personality traits, pedagogical skills and content knowledge, and professional skills and classroom behaviors. They concluded that 
effective English teachers were good at understanding students, teaching English language skills, managing classroom effectively, using technology and visual materials well.

Dincer et al. (2013) summarized that effective English teachers were good at providing stress free learning environment, English language knowledge, classroom management, and having good personalities. Ozkan and Mutlu (2017) emphasized that effective English teachers included those providing help to students, knowing about the target culture, and possessing positive characteristics. Focusing on the knowledge about the target culture, the same finding has shown in Celik et al, (2013) and Demiroz and Yesilyurt (2015), however, it was not viewed as an important aspect in the studies of Doro and T. Balla, (2014). Additionally, cross-cultural perspective was also vital in Walker (2011).

Moonsrakoo et al. (2015) concluded that knowledge, skill and personal quality were considered 3 main aspects of English teachers' competency with related 14 indicators. Knowledge covers four indicators, including linguistics, and English teaching curriculum, students, teaching methodology and technique. Skill covers seven indicators, namely communication skill, English skills, learning management skill, technology skill, measurement and evaluation skill, team working skill, and selfdevelopment skill. Personal quality covers three indicators, including motivation, love learning, and personality. Considering each indicator, it was found that motivation, love learning, knowledge of teaching methodology and technique, personality, English skills, team working skill, measurement and evaluation skill, communication skill, learning management skill, knowledge of English teaching curriculum and knowledge of linguistic were ranked as the most important to the least important indicators respectively.

\section{English Proficiency of English Language Teachers}

According to Renandya (2018), language proficiency was one of the distinctive features enhancing an English teacher's professional knowledge. A professional language teacher was expected to have sufficient content knowledge of English language, pedagogical content knowledge of how to teach English, and sufficient proficiency in English in order to perform their English teaching tasks effectively. English lessons were delivered more smoothly and efficiently by teachers possessing proficient levels of English. Studies showed that English teachers with a higher proficiency level seemed to be more skilled at using English to complete classroom tasks and provide appropriate language support to their students.

Teaching English in Thailand is in English as a Foreign Language (EFL) context. Most English teachers are non-native speakers of English graduating from English Teacher Education programs nationwide. English proficiency was determined as the first competence needed by effective Thai English language teachers. Recently, the Ministry of Education has used CEFR framework to evaluate and set English proficiency standards for Thai students in every educational level, That is, Grade 6 students should reach A1, Grade 9 for A2, Grade 12 for B1, and bachelor's degree graduates for B2 (Anantapool et al., 2018). This seems to be the assumption that proficiency in English 
language has a noteworthy relationship with the student's academic achievement. Thai teachers' expected English proficiency level is at B2 level of CEFR (Franz \& Teo, 2017, Watson Todd, 2016). With B2 level, the teachers are classified as upperintermediate user of English. English language teachers play key roles in developing students' English language proficiency; consequently, they should acquire higher English language proficiency levels than those of their students. In fact, Thai English language teachers who teach in secondary schools nationwide are required to have English proficiency level of B2 or higher of CEFR. Significantly, English teacher education programs should provide ample learning support to student teachers in order to improve their English proficiency to become effective English teachers (Hadi, 2019).

\section{METHOD}

\section{Research Design}

The Delphi technique and an exploratory sequential design (Creswell \& Plano Clark, 2011) were employed (see Figure 1) with three phrases of study: a qualitative and two quantitative phases. The Delphi technique included gathering qualitative data from a group of anonymous experts. Then, the qualitative data were analyzed and used to develop instruments for quantitative data collection to reach the consensus of the experts about qualifications of English teachers in the South of Thailand. The exploratory sequential design consisted of a qualitative phase of data collection and analysis followed by the instruments development to collect quantitative data (Greene et al., 1989). For this study, the qualitative data about the qualifications of English teachers obtained from the open-ended questionnaire and interview were used to construct rating scale questionnaires for collecting quantitative data.

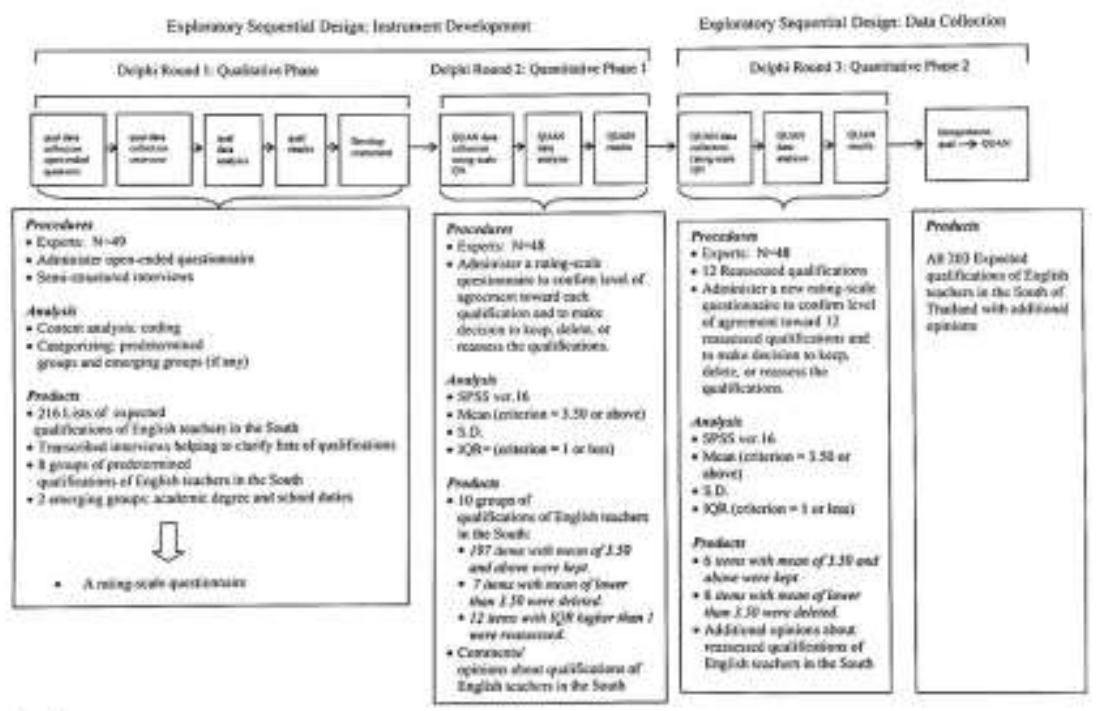

Figure 1

Research design (adapted from Creswell \& Plano Clark, 2011) 


\section{Qualitative Phase: Delphi Round 1 Participants}

49 experts from 5 panels ( 3 ex- and present presidents of Thailand Teaching English to Speakers of Other Languages (TESOL) Organization, 13 heads of English departments in schools with English Ordinary National Education Test (O-NET) scores higher than national mean scores, 14 outstanding teachers receiving national award in English teaching, 12 lecturers in English teacher education production institutions, and 7 experts from different study fields, including culture, social science, curriculum and instruction, educational administration and STEM education.

\section{Instruments}

There were two main instruments utilized in this round, including an open-ended questionnaire and a semi-structured interview. An open-ended questionnaire comprised two parts. The first part aimed to elicit the experts' personal information while the second one comprised two questions asking the experts to express their opinions toward the qualifications of English language teachers in the South of Thailand. The questionnaire was in Thai language to avoid language barrier asking: 1) In the next five to ten years, what qualifications should English language teachers in the South of Thailand have? You can express your opinions about knowledge, skills, abilities, personalities, professionalism, etc. You can express as many opinions as you can. and 2) What specific qualifications should English language teachers in the South of Thailand have to differentiate them from general English teachers and those teaching in other region of Thailand. You can express your opinions about knowledge, skills, abilities, personalities, professionalism, etc. You can express as many opinions as you can. The semi-structured interview was employed after the researcher received the responses from the experts to gain in-depth understanding about their suggested qualifications. The interview was done face-to-face, through telephone, Facebook or LINE application.

\section{Data Collection Procedure}

The qualitative data collection took place during January to July 2019. To begin, the researcher contacted 55 experts by meeting them individually to invite them to participate in the study and inform them the details of the study. Only 49 experts agreed to take part in the study, the researcher explained the directions and data collection procedures to the experts. More importantly, the experts were confirmed that their personal information and opinions will be kept confidentially. Then, the questionnaires were distributed to the experts by mail, by e-mail and by hand. The researcher contacted the experts regularly to answer their questions about the questionnaires. After the researcher received the questionnaire, the semi-structured interview was employed with the experts to give more information about unclear responses.

\section{Data Analysis}

The responses derived from the open-ended questionnaires were analyzed by using content analysis. The data were coded and categorized according to the 8 predetermined groups: language proficiency, professional content knowledge, pedagogical 
competence, technological competence, contextual competence, personalities, professionalism and global competence, generated from reviewed literature by the researcher based on Mishra and Koehler, 2006; SESMEO INNOTECH, 2010; Teacher Council of Thailand (TCT), 2013; and Teaching English to Speakers of Other Languages (TESOL), 2010. Any emerging groups, other qualifications that cannot be categorized to the 8 pre-determined groups, were also accepted. To ensure the validity and credibility of the qualitative data, the researcher used multiple analysts to analyze the data.

\section{Quantitative Phase 1: Delphi Round 2}

\section{Participants}

The same groups of experts were asked to take part in this data collection round. However, only 48 out of 49 experts agreed to continue being the experts.

\section{Instruments}

A rating-scale questionnaire was developed by using 216 qualifications of English language teachers in the South of Thailand derived from the open-ended questionnaire and the interview in Delphi Round 1. The questionnaire consisted of 216 qualifications of English language teachers in the South of Thailand arranged in 10 groups of qualifications respectively. The questionnaire aimed to elicit the experts' level of agreement toward each qualification of English language teachers in the South of Thailand and to make decision to keep, delete, or reassess the qualifications. The questionnaire consisted of two parts. The first part gave general information about the questionnaire, and the number of qualifications under each qualification group and definitions of eight qualification group. The second part, as shown in Figure 2, presented all qualifications along with rating-scale for the experts to confirm each qualification by rating their levels of agreement ranging from strongly agree (5), agree (4), moderately agree (3), disagree (2), and strongly disagree (1).

\section{Data Collection Procedure}

The first quantitative data collection took place during November and December 2019. The researcher contacted the experts individually to explain the details in the questionnaire. The questionnaires were distributed to the experts by mail, by e-mail, by hand, through Facebook or LINE application. The researcher contacted the experts regularly to answer their questions about the questionnaire.

\section{Data analysis}

The responses derived from the questionnaires were analyzed by using the Statistical Package for Social Sciences (SPSS) version 16. The data were analyzed for mean, standard deviation (S.D.) and interquartile range (IQR). Any items with mean lower than 3.50 were deleted, those with mean of 3.50 and above with IQR of 1 or less were kept as agreed qualifications, while those with mean of 3.50 and above and IQR more than 1 were contained in a new rating-questionnaire which would be sent to the experts again for reassessment in Delphi Round 3. 


\section{ROUND 2 Questionnaire \\ Future Qualifications of English Teachers in the South of Thailand}

Instructions: Place a check mark $(\checkmark)$ in the box that corresponds to your levels of agreement ranging from strongly agree (5), agree (4), moderately agree (3), disagree (2) and strongly disagree (1) toward the following qualifications of English teacher in the South of Thailand. You can include your opinions or reasons in the blank where indicated.

\begin{tabular}{|c|c|c|c|c|c|c|c|}
\hline \multirow{3}{*}{ Item } & \multirow{3}{*}{$\begin{array}{l}\text { You agree that English teachers in the South of } \\
\text { Thailand should... }\end{array}$} & \multicolumn{5}{|c|}{ Levels of agreement } & \multirow{2}{*}{ Opinions/Reasons } \\
\hline & & 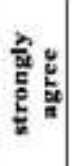 & 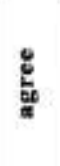 & 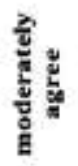 & $\frac{\text { हैँ }}{\frac{\pi}{2}}$ & 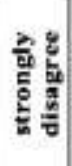 & \\
\hline & & 5 & 4 & 3 & 2 & 1 & \\
\hline \multicolumn{8}{|c|}{ Language proficiency } \\
\hline 1 & $\begin{array}{l}\text { Master English proficiency at } \mathrm{C} 2 \text { level of the } \\
\text { Common European Framework of Reference for } \\
\text { Languages (CEFR). }\end{array}$ & & & & & & \\
\hline 2 & $\begin{array}{l}\text { Master English proficiency at the pass criteria at B2 } \\
\text { level of the Common European Framework of } \\
\text { Reference for Languages (CEFR). }\end{array}$ & & & & & & \\
\hline 3 & $\begin{array}{l}\text { Have English proficiency that meets the standards } \\
\text { designated by the Ministry of Education. }\end{array}$ & & & & & & \\
\hline
\end{tabular}

Figure 2

Delphi round 2 questionnaire

\section{Quantitative Phase 2: Delphi Round 3}

\section{Participants}

The same groups of 48 experts were asked to take part in this data collection round.

Instruments

A new rating-scale questionnaire contained the 12 qualifications which needed reassessment from Delphi Round 2 along with mean, S.D. and opinions of experts from Delphi Round 2. The questionnaire aimed to have the experts reassess each qualification by rating their levels of agreement on each qualification (shown in Figure 3).

\section{Data Collection Procedure}

The second quantitative data collection for Delphi Round 3 took place during January and February 2020. The researcher contacted the experts to explain the reassessment process.

\section{Data Analysis}

The data analysis followed the same process of Delphi Round 2. 
ROLND 3 Ouectionnaire

Future Qualificatioes of English Teachers in the Seuth of Thailand

Instructies: Plase a check mark ( $V$ ) in the box tas corresponds to your levels of ageenent ranging froes strongly agee (5) apee (4). modentely agree (3).

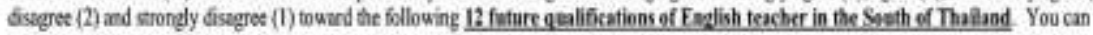
inclade your opitions or stasons in the blank where indicatod.

\begin{tabular}{|c|c|c|c|c|c|c|c|c|c|c|}
\hline \multirow{3}{*}{$\mathrm{lnm}$} & \multirow{3}{*}{ 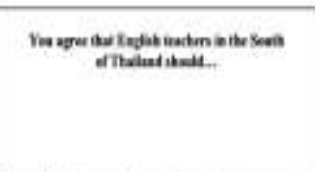 } & \multirow{3}{*}{$\overline{\mathrm{x}}$} & \multirow{3}{*}{ so. } & \multirow{3}{*}{ 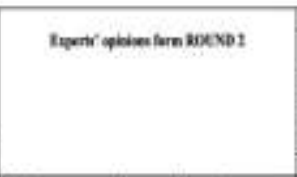 } & \multicolumn{5}{|c|}{ 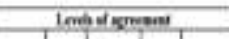 } & \multirow[b]{2}{*}{ 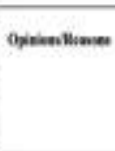 } \\
\hline & & & & & 彭 & $\vdots$ & $\frac{1}{2}$ & $\frac{1}{4}$ & $\frac{1}{1}$ & \\
\hline & & & & & 5 & 7 & 3 & 1 & 1 & \\
\hline$T$ & 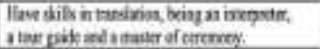 & 38 & H & 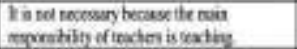 & & & & & & \\
\hline 2 & 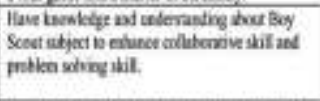 & 377 & ing & 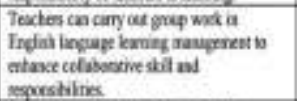 & & & & & & \\
\hline 3 & 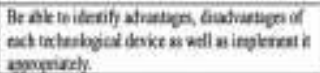 & 404 & II & 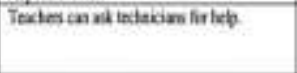 & & & & & & \\
\hline 4 & 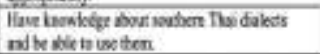 & 195 & 8 & 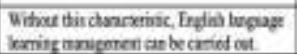 & & & & & & \\
\hline
\end{tabular}

Figure 3

Delphi round 3 questionnaire

\section{FINDINGS AND DISCUSSION}

\section{Qualitative Phase: Delphi Round 1}

The analysis of the data derived from the open-ended questionnaire and the interview responses found that 216 qualifications were suggested by the experts. Then, they were categorized into 10 groups, 8 pre-determined groups and 2 emerging groups (shown in Table 1).

Table1

Overall qualifications of English language teacher in the south of Thailand

\begin{tabular}{llll}
\hline Categories & $\begin{array}{l}\text { Number of } \\
\text { qualifications }\end{array}$ & Categories & $\begin{array}{l}\text { Number of } \\
\text { qualifications }\end{array}$ \\
\hline 1. Language proficiency & 16 & 6. Personalities & 46 \\
\hline 2. Professional content knowledge & 34 & 7. Professionalism & 24 \\
\hline 3. Pedagogical competence & 40 & 8. Global competence & 12 \\
\hline 4. Technological competence & 15 & 9. Academic degree & 2 \\
\hline 5. Contextual competence & 23 & 10.School duties & 2 \\
\hline Total & 216 & & \\
\hline
\end{tabular}

From Table 1, the most expected qualifications were in the categories of personalities (46 items) and pedagogical competence (40 items). This means that English teachers in the South of Thailand should have positive, desirable, inspiring and encouraging personalities and ability to put teaching and learning principles into practice. These results were in line with Virgiyanti et al. (2016) which showed that personal skills such as fair, friendly, enthusiastic and responsible, were perceived by students as the most effective characteristics of junior high school English teachers while teachers' perceptions were on both pedagogical skills and personal skills such as fair, friendly, cheerful and entertaining. Besides, the findings were similar to the study of Park and 
Lee (2006) ranking pedagogical knowledge as the second important characteristics of effective English teachers. However, the finding of the present study contrasted with the study of Hien (2019) revealing that personal characteristic was the least significant aspect while pedagogical skills was the most expected qualities of pre-service English teachers. The details of all qualifications for each qualification groups were as the followings:

\section{Qualification group 1: Language Proficiency}

Being English teachers in the South of Thailand required some specific details of language proficiency with shown in Table 2 .

Table 2

Qualifications for language proficiency

\begin{tabular}{|c|c|c|c|}
\hline Language proficiency & English Language Skills & Skills Requiring English & Being Role Model \\
\hline $\begin{array}{l}\text { Master English } \\
\text { proficiency at C2 level } \\
\text { of the Common } \\
\text { European Framework } \\
\text { of Reference for } \\
\text { Languages (CEFR). } \\
\text { Master English } \\
\text { proficiency at the pass } \\
\text { criteria at B2 level of } \\
\text { the Common European } \\
\text { Framework of } \\
\text { Reference for } \\
\text { Languages (CEFR). } \\
\text { Have English } \\
\text { proficiency that meets } \\
\text { the standards } \\
\text { designated by the } \\
\text { Ministry of Education. }\end{array}$ & $\begin{array}{l}\text { Master English listening, speaking, reading and } \\
\text { writing skills at good level with accuracy, } \\
\text { fluency and complexity suitable for various } \\
\text { situations and contexts. } \\
\text { Have native-like listening, speaking, reading } \\
\text { and writing skills of English. } \\
\text { Master English listening and speaking skills for } \\
\text { communication at good level. } \\
\text { Master English writing skills in various } \\
\text { language functions. } \\
\text { Be able to pronounce English consonant and } \\
\text { vowel sounds accurately according to IPA. } \\
\text { Be able to pronounce words and sentences with } \\
\text { accurate stress and intonation. } \\
\text { Be able to pronounce words and sentences with } \\
\text { accurate stress and intonation. } \\
\text { Be able to pronounce problematic sounds for } \\
\text { people in the South correctly. } \\
\text { Have communicative competence. }\end{array}$ & $\begin{array}{l}\text { Be able to make } \\
\text { presentations in English. } \\
\text { Have skills in translation, } \\
\text { being an interpreter, a } \\
\text { tour guide and a master } \\
\text { of ceremony. }\end{array}$ & $\begin{array}{l}\text { Be a good role } \\
\text { model in speaking } \\
\text { English for } \\
\text { learners. } \\
\text { Be a good role } \\
\text { model in listening, } \\
\text { speaking, reading } \\
\text { and writing English } \\
\text { for learners. }\end{array}$ \\
\hline
\end{tabular}

As Table 2 describes, having language proficiency at a specified level has been prominent. This finding was consistent with prior studies by Mahmoud and Thabet (2012), Park and Lee (2006), and Wichadee (2010) which highlighted having high level of English proficiency as one of core competencies of effective English teachers. This was also alongside the guidelines of English proficiency levels for teachers of the Ministry of Education specifying that English teachers or primary level should master B1 proficiency level while those in secondary level have to master B2 level of the Common European Framework of Reference for Languages (CEFR). All four language skills with good and native-like levels have been suggested while both listening and speaking skills have been obviously paired together. Only writing was solely mentioned. This also confirmed the findings of Brosh (1996), Khan (2010) and Virgiyanti et al. (2016) which emphasized the importance of having good command of target language both written and communication for effective English teachers.

In addition, pronunciation for both segmental and supra segmental features, have been identified with qualities, such as near-native and accurate levels. Since pronunciation was viewed as a necessary competency of English language (EL) teachers (Virgiyanti et al. 2016; Yasmin \& Islam 2018), this result was in agreement with the study of Shahzada (2012) asserting that EL teachers should be well-trained for accurate 
pronunciation to develop better English pronunciation for their learners. Furthermore, having skills requiring English such as presentation, translations, being an interpreter, a tour guide and a master of ceremony, have been suggested. Interestingly, being an interpreter, a tour guide and a master of ceremony were specific to this study because they were not mentioned in other studies.

Last but not least, being a good role model in overall or separate English skills was also reported. Being a role model for learners was in agreement with the study of Muir et al. (2019). They conducted a large-scale international investigation about the role models of English language learners. The results showed that the learners had their teachers as their personally known role model with the highest percentage. For the characteristics they valued in their role models, four dimensions, namely overall command of English, paralinguistic features, personal attributes and accent/variety of English, were reported.

\section{Qualification group 2: Professional Content Knowledge}

Both content knowledge related to English language and teaching profession were quite crucial for English teachers in the South of Thailand as can be seen in Table 3.

Table 3

Qualifications for professional content knowledge

\begin{tabular}{|c|c|}
\hline Content knowledge related to English language & Content knowledge related to teaching profession \\
\hline \multirow{3}{*}{$\begin{array}{l}\text { Have good knowledge of English vocabulary relevant to teaching levels. } \\
\text { Have knowledge of vocabulary in other study fields, both in science and } \\
\text { social sciences. }\end{array}$} & ave knowledge and understanding about \\
\hline & \\
\hline & lesson plans. \\
\hline $\begin{array}{l}\text { Have good knowledge of English grammar relevant to teaching levels. } \\
\text { Have knowledge and understanding about advanced English grammar. }\end{array}$ & about various branches of \\
\hline \multirow{2}{*}{ Have profound knowledge and understanding about linguistics. } & $\begin{array}{l}\mathrm{ps} \\
\mathrm{B}\end{array}$ \\
\hline & ors appropriatery. \\
\hline Have knowledge about language learning strategies. & \\
\hline \multirow{2}{*}{$\begin{array}{l}\text { Have knowledge about the contents of other subjects, both in science and } \\
\text { social sciences. }\end{array}$} & \\
\hline & \\
\hline Have knowledge and understanding about Thai culture. & \\
\hline $\begin{array}{l}\text { Have knowledge and understanding about western culture and the culture } \\
\text { of native speakers. }\end{array}$ & $\begin{array}{l}\text { Have knowledge and ability in classroom } \\
\text { management. }\end{array}$ \\
\hline $\begin{array}{l}\text { Have knowledge and understanding about international culture. } \\
\text { Have knowledge and understanding about western literatures. }\end{array}$ & Have knowledge and ability in various methods of \\
\hline $\begin{array}{l}\text { Have knowledge and understanding about the differences between } \\
\text { English and Thai languages. }\end{array}$ & $\begin{array}{l}\text { measurements and evaluations. } \\
\text { Have knowledge and ability to develop English } \\
\text { tests. }\end{array}$ \\
\hline $\begin{array}{l}\text { Have knowledge and understanding about the differences between English } \\
\text { and Bahasa Maleyu (Malay) languages. }\end{array}$ & $\begin{array}{l}\text { Have knowledge about learning resources for self- } \\
\text { study by learners. }\end{array}$ \\
\hline $\begin{array}{l}\text { Have knowledge and understanding about the similarities between English } \\
\text { and Arabic languages. }\end{array}$ & $\begin{array}{l}\text { Have knowledge and understanding about the } 21^{\text {st }} \\
\text { century skills including collaborative skill, critical }\end{array}$ \\
\hline \multirow{2}{*}{$\begin{array}{l}\text { Have knowledge and understanding about second language acquisition. } \\
\text { Have knowledge and understanding about Global Englishes, World }\end{array}$} & \\
\hline & \\
\hline $\begin{array}{l}\text { Englishes, English as an International Language (EIL), English as a lingual } \\
\text { Franca (ELF). }\end{array}$ & $\begin{array}{l}\text { Have thinking skills like analytical thinking, } \\
\text { creative thinking and critical thinking. }\end{array}$ \\
\hline \multirow{2}{*}{$\begin{array}{l}\text { Have knowledge and understanding about history and evolution of English } \\
\text { language. }\end{array}$} & about Boy \\
\hline & \\
\hline \multirow{2}{*}{\multicolumn{2}{|c|}{$\begin{array}{l}\text { Have knowledge and understanding about English language related to } \\
\text { Christianity. }\end{array}$}} \\
\hline & \\
\hline \multicolumn{2}{|l|}{$\begin{array}{l}\text { Have knowledge and understanding about English language related to } \\
\text { tourism in the South. }\end{array}$} \\
\hline \multicolumn{2}{|l|}{$\begin{array}{l}\text { Have knowledge and understanding about English language related to } \\
\text { southern culture. }\end{array}$} \\
\hline
\end{tabular}
southern culture.

As shown in Table 3, English teachers in the South of Thailand must be knowledgeable not only about the contents of English language but also those of teaching profession. 
The importance of the English language contents and teaching profession contents could be seen from the two specific required courses, including teaching profession courses and English language courses, mentioned in standard of qualification and specification for bachelor of education of Ministry of Education (2011, 2019). This also was consistent to the content domains of Chea (2014).

From the table, the mastery of content knowledge relevant to English language outweighed the content knowledge relevant to teaching profession. For the content knowledge of English language, linguistics, vocabulary, grammar rules, second language acquisition, World Englishes, culture and intercultural competence have been covered. The aforementioned contents were also asserted in previous studies, including linguistics (Chea, 2014; Moonsrakoo, 2015), vocabulary and grammar (Virgiyanti et al. 2016), grammar, syntax, pronunciation and literature (Chea, 2014; Yasmin \& Islam 2018), target culture (Chea, 2014; Demiroz \& Yesilyurt, 2015; Ozkan \& Mutlu, 2017), inter- or cross-cultural (Savu et al., 2014; Walker, 2011).

For the knowledge relevant to teaching profession, $21^{\text {st }}$ century skills have been highlighted. This concurred with the professional knowledge of Teacher Council of Thailand (2013). Because teachers of any subjects in primary and secondary schools have been assigned to teach Boy Scout subject, having knowledge of Boy Scout was proposed by the experts.

"English teachers need to have knowledge of Boy Scout in order to enhance team working skills, problem solving skills, living together as a group, friendliness and helpfulness." (Expert 17)

\section{Qualification group 3: Pedagogical Competence}

English teachers in the South of Thailand should have pedagogical knowledge and abilities to manage and design learning based on various teaching theories and principles as presented in Table 4 .

Table 4

Qualifications for pedagogical competence

\begin{tabular}{ll}
\hline Pedagogical Knowledge and Ability & Learning Management and Design Ability \\
\hline Have knowledge and understanding & Be able to manage learning based on student-centered learning. \\
about various theories, teaching & Be able to manage learning based on learning by doing. \\
methodologies, techniques and & Be able to manage learning based on active learning. \\
learning managements. & Be able to design learning based on backward design. \\
Have knowledge of how to teach. & Be able to manage learning based on project-based learning. \\
Be able to produce handmade & Be able to manage learning based on interdisciplinary learning. \\
teaching aids and develop teaching & Be able to use English classroom language and use English as a medium of teaching. \\
materials. & Be able to provide opportunities for learners to use English in classrooms. \\
Be able to produce teaching aids by & Be able to manage learning based on communicative language teaching. \\
using local materials. & Be able to apply linguistics knowledge to learning management. \\
Be able to sing, dance, and compose & Be able to manage learning based on phonics teaching. \\
songs or jazz chants. & Be able to manage English learning for communication emphasizing on listening and \\
Be able to create classroom & speaking skills for careers. \\
atmosphere enhancing English & Have knowledge and understanding about and being able to manage learning based on \\
learning. & inclusive learning. \\
Be facilitators. & Be able to manage learning to develop analytical thinking skill, creative thinking skill, \\
Be entertainers. & and critical thinking skills. \\
Be able to arrange English camps. & Be able to manage learning based on constructivism. \\
Be able to train learners for giving & Be able to manage learning enhancing learners' self-directed learning. \\
speech, telling stories, performing & Be able to manage learning based on experiential teaching. \\
skits. & Be able to design English learning management integrated with general knowledge, \\
\hline
\end{tabular}




\begin{tabular}{ll}
\hline Pedagogical Knowledge and Ability & Learning Management and Design Ability \\
\hline Be able to compose and direct & current events and daily life information. \\
English plays. & Be able to design English learning management emphasizing learners to apply what \\
Have knowledge and ability to & they have learnt in their daily life. \\
conduct classroom action research to & Be able to manage English learning by using games, songs, and jazz chants. \\
solve real problems in the & Be able to manage learning by using authentic materials. \\
classrooms. & Be able to manage learning connected to tourism in the South. \\
& Be able to design English learning management by integrating it with southern \\
cultures and life style of southerners. & Be able to design English learning management by using southern cultures like \\
shadow puppet or Manohra. & Be able to design various English learning managements to suit learners' diversity in \\
abilities, aptitudes and religions. & Be able to manage English learning relevant to learners' interests and needs. \\
Be able to manage English learning relevant to the needs of parents or communities. \\
Be able to manage English learning activities not in opposition to Islamic principles.
\end{tabular}

As can be seen from Table 4, English teachers in the South of Thailand should have pedagogical knowledge of various theories, teaching methodologies, techniques and ability to prepare materials and play different roles to promote successful teaching. Moreover, they should have ability to manage and design various learning managements to suit the diversity of learners, parents and communities. This finding was similar to the study of Borg (2006), Celik et al. (2013) who studied the characteristics of EL teachers reporting that English teachers should be good at teaching English skills, managing classroom effectively and having progressive teaching methodologies. In line with that, the significance of possessing pedagogical knowledge, utilizing variety of teaching skills, teaching techniques to promote comprehensible and effective teaching was indicated (Hien, 2019; Shuman, 1987).

\section{Qualification group 4: Technological Competence}

Being able to apply both learning resources and technologies were essential for English teachers in the South (see Table 5).

Table 5

Qualifications for technological competence

\begin{tabular}{ll}
\hline Knowledge and Ability to Apply Technologies & Incorporating technologies in Teaching and Learning \\
\hline $\begin{array}{l}\text { Have digital literacy. } \\
\text { Have knowledge and ability to use modern educational technologies } \\
\text { and teaching innovations. }\end{array}$ & $\begin{array}{l}\text { Be able to use technologies in creating teaching aids, } \\
\text { activities and learning management effectively and } \\
\text { interestingly. }\end{array}$ \\
$\begin{array}{l}\text { Have knowledge and ability to manage big data. } \\
\text { Be able to use technologies in learning evaluation and } \\
\text { giving feedbacks } \\
\text { contents and learners. }\end{array}$ & $\begin{array}{l}\text { Be able to create massive open online courses } \\
\text { (MOOCs). }\end{array}$ \\
$\begin{array}{l}\text { Have retrieval skill through the Internet. } \\
\text { Be able to use technologies to retrieve, adapt, and present information } \\
\text { appropriately. }\end{array}$ & $\begin{array}{l}\text { Be able to manage learning through social media } \\
\text { networks. }\end{array}$ \\
$\begin{array}{l}\text { Be able to use computers, multimedia and language laboratories. } \\
\text { Be able to produce multimedia and interactive media by using various } \\
\text { technological devices. Be able to identify advantages, disadvantages of }\end{array}$ & $\begin{array}{l}\text { Bearners anywhere and anytime. } \\
\text { each technological device and implement it appropriately. }\end{array}$ \\
$\begin{array}{l}\text { Be able to evaluate technology skill based on TESOL Technology } \\
\text { Standard Framework. }\end{array}$ &
\end{tabular}

As Table 5 reports, being able to use and apply both online and offline resources and technologies were vital for English teachers in the South. This result was in accordance with Technological Pedagogical Content knowledge (TPACK) framework of Mishra and Koehler (2006) describing that teachers needed to know how to integrate 
technology into their teaching successfully. Additionally, being well informed about educational technologies, digital skills, Information Communication Technology (ICT) and Information Technology (IT) as well as incorporating technologies (Gilakjani, 2017; Sriprom et al., 2019; Yasmin \& Islam 2018) and social media (Sriprom et al., 2019 ) in teaching and learning process of EL teachers were highlighted.

\section{Qualification group 5: Contextual Competence}

Understanding local context was also important for English teachers in the South. The details of contextual competence were in Table 6.

Table 6

Qualifications for contextual competence

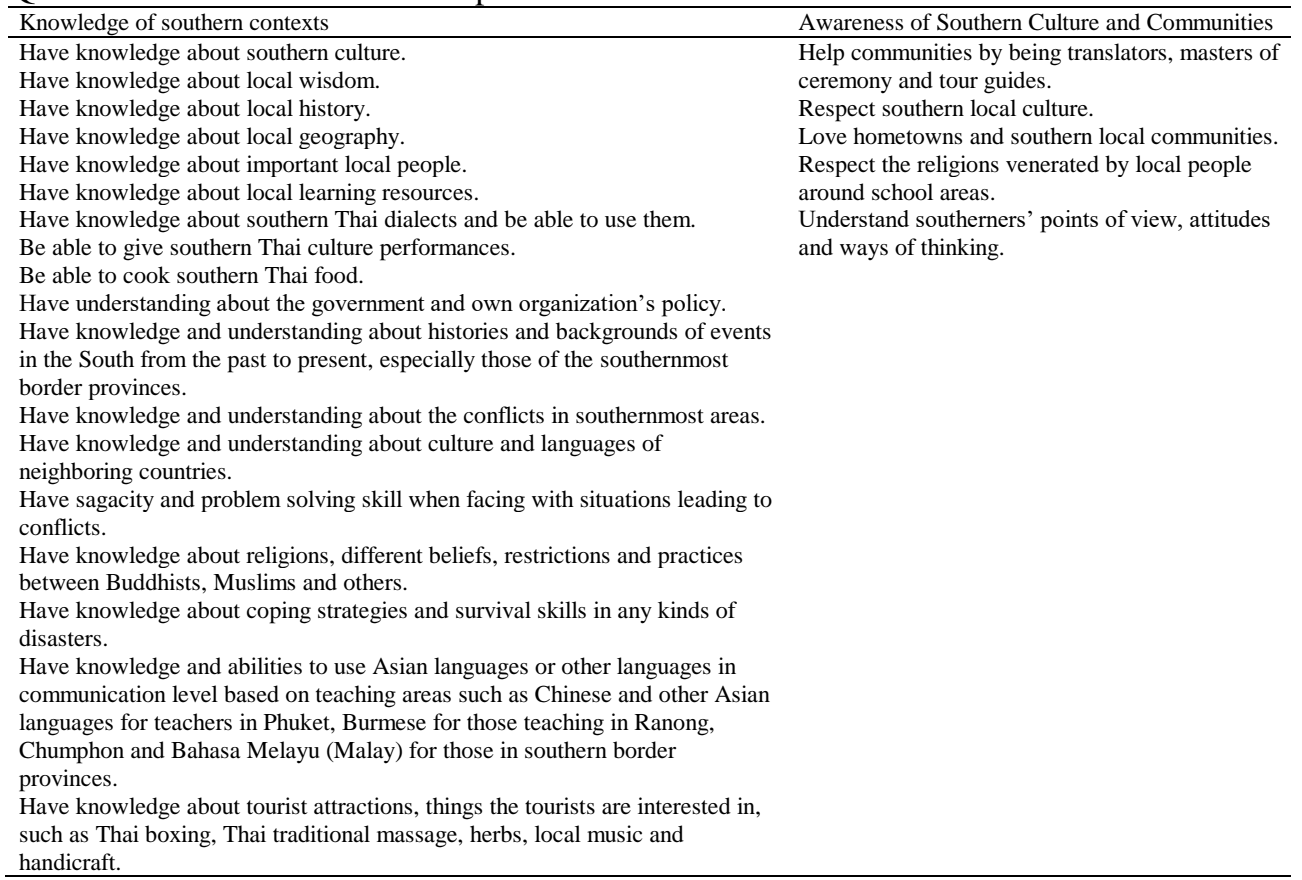
handicraft.

As Table 6 illustrates, in order to teach English in the South of Thailand successfully, English teachers should be aware of the uniqueness of southern contexts, including history, important events, tourist attractions, local wisdom, cultures, religions and the conflicts within southernmost border provinces. These qualifications were quite unique for this study. In this regard, EL teachers' awareness about learners' cultural backgrounds, a specific background of local community and some social factors affecting overall learning of learners could enhance English learning success (Khan, 2010; Izadinia, 2012; Medgyes, 1994; Tangcharaen et al., 2016).

These were also in consistence with the results of Promsaka Na Sakolnakorn et al. (2016). They suggested guidelines for government policy to develop English learning in three southern border provinces of Thailand, including setting up a policy to recruit 
teaching staff who understand the local context because most students are Muslims and training Buddhists and foreign teachers to understand the local context.

\section{Qualification group 6: Personalities}

Personalities were the most suggested qualifications as illustrated in Table 7.

Table 7

Qualifications for personalities

\begin{tabular}{|c|c|c|c|}
\hline $\begin{array}{l}\text { Spirituality, Morality, } \\
\text { Ethics of Being Teachers }\end{array}$ & Positive and Desirable Personal Values & $\begin{array}{l}\text { Inspiring and Encouraging } \\
\text { Personalities }\end{array}$ & $\begin{array}{l}\text { Unique } \\
\text { Personalities }\end{array}$ \\
\hline $\begin{array}{l}\text { Have teachers' } \\
\text { spirituality. } \\
\text { Have morality, ethics, } \\
\text { and code of ethics of } \\
\text { being teachers. } \\
\text { Be democratic. } \\
\text { Have faith in } \\
\text { constitutional monarchy. }\end{array}$ & $\begin{array}{l}\text { Dress politely, modestly and trendy. } \\
\text { Have universality but not against Thai culture. } \\
\text { Speak politely, modestly, sweetly and gently. } \\
\text { Speak loudly and clearly } \\
\text { Can adjust one's own self quickly. } \\
\text { Be public-minded. } \\
\text { Have social etiquettes in living with others like } \\
\text { using restrooms and elevators. } \\
\text { Be disciplined. } \\
\text { Be graceful. Be handsome or beautiful. } \\
\text { Have self-confidence. } \\
\text { Be brave to do different and right things. } \\
\text { Be assertive and brave to make decisions. } \\
\text { Have leadership. } \\
\text { Have good interpersonal skill and be cheerful. } \\
\text { Have compromising skills and negotiation ability } \\
\text { when facing critical situations. } \\
\text { Be responsible for oneself, work and others. } \\
\text { Be patient. } \\
\text { Be able to work as a team. } \\
\text { Be humble. } \\
\text { Have a good sense of humor. } \\
\text { Have flexibility. } \\
\text { Have positive attitude. Be optimistic. } \\
\text { Be punctual. } \\
\text { Be observant. } \\
\text { Have a good memory. } \\
\text { Be sincere. } \\
\text { Be able to keep secrets. } \\
\text { Be enthusiastic and active. } \\
\text { Be indomitable and be able to control tempers well. } \\
\text { Be able to control tempers and express opinions } \\
\text { appropriately through social networks. } \\
\text { Be honest, not be greedy. } \\
\text { Be focused on working for learners' benefits. } \\
\text { Be able to distinguish the good and the bad. }\end{array}$ & $\begin{array}{l}\text { Love and be merciful to } \\
\text { others. } \\
\text { Be generous to learners } \\
\text { and colleagues. } \\
\text { Be a good listener for } \\
\text { learners. } \\
\text { Be a good listener for } \\
\text { colleagues. } \\
\text { Be able to persuade } \\
\text { learners to love and have } \\
\text { positive attitude toward } \\
\text { English. } \\
\text { Be a role model in } \\
\text { dressing for learners. } \\
\text { Be a role model in } \\
\text { morality and ethics for } \\
\text { learners. }\end{array}$ & $\begin{array}{l}\text { Dress } \\
\text { expressing } \\
\text { southern } \\
\text { identity. } \\
\text { Speak } \\
\text { frankly. } \\
\text { Love } \\
\text { companions. } \\
\text { Be self- } \\
\text { sufficient. }\end{array}$ \\
\hline
\end{tabular}

As Table 7 describes, being English teachers required diverse personalities, including spirituality, morality and ethics of being teachers, positive and desirable personal values, inspiring, encouraging personalities and unique personalities. The suggested personalities were in line with some previous studies, namely 1) maintain moral and ethical standards of being teachers (Mayahi \& Mayahi, 2014; Teacher Council of Thailand, 2013); 2) dress politely, modestly and trendy (Ghasemi \& Hashemi, 2011); 3) be cheerful (Virgiyanti et al., 2016); 4) have a good sense of humor (Dincer et al., 2013; Ozkan \& Mutlu, 2017; Songsirisak, 2017); 5) be flexible (Dora \& Balla, 2014; Mayahi \& Mayahi, 2014), 6) be punctual (Virgiyanti et al., 2016); 7) be able to persuade learners to love English (Virgiyanti et al., 2016); 8) be a role model in dressing for 
learners (Khan, 2010); and 9) be a role model in morality and ethics for learners (Tangcharaen et al., 2016; Teacher Council of Thailand, 2013).

Nevertheless, in this study, some unique personalities were revealed such as dressing expressing southern identity, speaking frankly, loving companions and being selfsufficient. In response to the encouragement of the government for educational personnel nationwide to wear clothes made from national or local fabrics. Both speaking frankly and loving companions have also been identified as distinct personality traits of people in the South of Thailand (Yoothong, 2004). Being self-sufficient was the application of the King's philosophy of sufficiency economy that has been well known and carried out among Thai citizens nationwide.

\section{Qualification group 7: Professionalism}

Some qualifications to promote professionalism for English teachers in the South were suggested in Table 8 .

Table 8

Qualifications for professionalism

\begin{tabular}{|c|c|}
\hline Things to Do Regularly & Abilities and Skills to Develop. \\
\hline Love reading and be willing to acquire lifelong learning relevant to "Learning: & Be willing to develop academic work \\
\hline The Treasure Within" of UNESCO. & continually to promote their professional \\
\hline Be an active knowledge seeker. & levels. \\
\hline $\begin{array}{l}\text { Be interested in improving oneself based on the results of English language } \\
\text { proficiency tests. }\end{array}$ & $\begin{array}{l}\text { Be willing to study visit other } \\
\text { organizations. }\end{array}$ \\
\hline $\begin{array}{l}\text { Be interested in participating in conferences or seminars continually at least } \\
\text { twice a year. }\end{array}$ & $\begin{array}{l}\text { Be interested in being a national role } \\
\text { model in teaching English. }\end{array}$ \\
\hline Plan for further studies in higher levels such as diploma and Master's degree. & Be interested in being an international \\
\hline Be interested in participating in Professional Learning Community (PLC). & role model in teaching English. \\
\hline $\begin{array}{l}\text { Be willing to implement quality cycle of PDCA to improve the quality of } \\
\text { working. }\end{array}$ & $\begin{array}{l}\text { Be interested in making network with } \\
\text { teachers in Malaysia and Singapore. }\end{array}$ \\
\hline Be willing to share knowledge and teaching aids with other teachers. & Be interested in gaining more knowledge \\
\hline Be interested in being members of national English teaching organizations. & to create new things for schools and \\
\hline Be interested in being members of international English teaching organizations. & communities. \\
\hline $\begin{array}{l}\text { Be able to communicate professionally in both verbal and non-verbal } \\
\text { communication. }\end{array}$ & $\begin{array}{l}\text { Be interested in writing academic articles } \\
\text { to be published nationally. }\end{array}$ \\
\hline Be able to coordinate with students, colleagues, and parents. & Be interested in writing academic articles \\
\hline Be able to communicate to develop mutual understanding and good relationship & to be published internationally. \\
\hline with local people having different cultures, languages, and religions. & $\mathrm{Be}$ interested in practicing national \\
\hline Be interested in broadening their knowledge according to growth mindset. & research presentations. \\
\hline $\begin{array}{l}\text { Be focused on performing morality and ethics of conducting academic work. } \\
\text { Accept and correct one's own mistakes. }\end{array}$ & $\begin{array}{l}\text { Be interested in practicing international } \\
\text { research presentations. }\end{array}$ \\
\hline
\end{tabular}

From Table 8, professionalism for English teachers covered things they should do regularly, abilities, and skills they needed to develop. These results were in accordance with the personal ethics of Teachers Council of Thailand (2013) stating that "Educational Professional Practitioners shall have self-discipline and improve their professional practice, personality and vision to keep up with the academic, economic, social and political development." Furthermore, this agreed with the study of Mayahi and Mayahi (2014) arresting that EL teachers should set goals for continued professional growth. It also echoed the study of Yasmin and Islam (2018) stressing that it was crucial for EL teachers to share their personal and academic experience, keep themselves in touch with the latest trends and issues in English language teaching by attending training, workshops, seminars, conferences to refresh knowledge and skills. 


\section{Qualification group 8: Global Competence}

To keep up with the rapidly changing world, some qualifications enhancing global competence were displayed in Table 9.

Table 9

Qualifications for global competence

\begin{tabular}{ll}
\hline Global Knowledge & Interdisciplinary Knowledge \\
\hline Learn, study and follow global news through various & Have knowledge about financial, economic, business and \\
medias like BBC News or Aljazeera. & entrepreneurial literacy. \\
Be well-rounded and have knowledge about daily & Have knowledge about human rights and fundamental law. \\
information. & Have knowledge about civil literacy. \\
Have knowledge and understanding about changes in global & Have knowledge about environment literacy. \\
society. & Have knowledge about intercultural society. \\
Have knowledge about global awareness. & Have knowledge about non-violence. \\
Have life skills. & Have self-defense skills like shooting and martial art. \\
\hline
\end{tabular}

As Table 9 displays, being aware of and well-rounded with global issues was also essential for English teachers. This was consistent with the study of Cates (2002) stressing that language teachers who kept update with global topics could improve students' knowledge and skills to deal with global issues. This also concurred the study of Jing (2013) exploring and reporting the beliefs and practices regarding global awareness of teachers of English as a foreign language. The teachers' views toward global awareness and its importance, relationship with English teaching and learning and with the gap between curriculum and practices were emphasized.

\section{Qualification group 9: Academic Degree}

English teachers in the South were expected to receive particular academic degrees, especially a degree in English language and English language teaching. A degree in English language or English language teaching has been identified as preferable degrees for English teachers in the South. According to Fareh (2010), only qualified EL teachers who had a degree in English language and teaching certificate could be allowed to teach. In relevant to this result, EL teachers with a degree in English perceived that they were well trained, get more exposure to English and had self-perception toward their English proficiency (Kaewwichian \& Jaturapitakkul, 2018).

\section{Qualification group 10: School Duties}

Not only teaching duties but also school duties were proposed for English teachers, particularly using office equipment at schools and doing ordinary work at schools like changing light bulbs and planting trees. Apart from teaching duties, English teachers should be responsible for other assigned duties at schools. This finding was in accordance with the study of Tangcharaen et al. (2016). They mentioned helping with other schools activities as one of key responsibilities of teachers.

\section{Quantitative Phase 1: Delphi Round 2}

As can be seen in Table 10, after all 216 qualifications were sent back to the same 49 experts participated in Delphi Round 1, 197 qualifications were kept because their mean scores were 3.50 and above. 7 qualifications were deleted because their mean scores were lower than 3.50. In addition, 12 qualifications needed reassessment because their mean scores were above 3.50 with IQR above 1 . 
Table 10

Kept, deleted and reassessed qualifications of English teachers in the south of Thailand

\begin{tabular}{|c|c|c|c|c|}
\hline Categories & Kept & Deleted & Reassessed & Total \\
\hline Language proficiency & 15 & 0 & 1 & 16 \\
\hline Professional content knowledge & 29 & 4 & 1 & 34 \\
\hline Pedagogical competence & 40 & 0 & 0 & 40 \\
\hline Technological competence & 14 & 0 & 1 & 15 \\
\hline Contextual competence & 19 & 2 & 2 & 23 \\
\hline Personalities & 42 & 0 & 4 & 46 \\
\hline Professionalism & 24 & 0 & 2 & 26 \\
\hline Global competence & 11 & 1 & 0 & 12 \\
\hline Academic degree & 2 & 0 & 0 & 2 \\
\hline School duties & 1 & 0 & 1 & 2 \\
\hline Total & 197 & 7 & 12 & 21 \\
\hline
\end{tabular}

The deleted qualifications (shown in Table 11) included: 1) have knowledge and understanding about the differences between English and Bahasa Maleyu (Malay) languages; 2) have knowledge and understanding about the similarities between English and Arabic languages; 3) have knowledge and understanding about history and evolution of English language; 4) have knowledge and understanding about English language related to Christianity; 5) be able to cook southern food; 6) respect the same religions venerated by local people around school areas and 7) have self-defense skills like shooting and martial art.

Table 11

Descriptive statistics of the deleted qualifications

\begin{tabular}{lccc}
\hline Qualifications & Mean & S.D. & IQR \\
\hline Professional content knowledge & 3.16 & .83 & 1.00 \\
\hline $\begin{array}{l}\text { 1.Have knowledge and understanding about the differences between } \\
\text { English and Bahasa Maleyu (Malay) languages. }\end{array}$ & 2.64 & .52 & 1.00 \\
\hline $\begin{array}{l}\text { 2.Have knowledge and understanding about the similarities between } \\
\text { English and Arabic languages. }\end{array}$ & 3.43 & .79 & 1.00 \\
\hline $\begin{array}{l}\text { 3.Have knowledge and understanding about history and evolution of } \\
\text { English language. }\end{array}$ & 3.22 & .69 & 1.00 \\
\hline $\begin{array}{l}\text { 4.Have knowledge and understanding about English language related to } \\
\text { Christianity. }\end{array}$ & & & \\
\hline$\quad$ Contextual competence & 3.45 & 1.00 & 1.00 \\
\hline 5.Be able to cook southern Thai food. & 2.52 & 1.06 & 1.00 \\
\hline 6. Respect the religions venerated by local people around school areas. & 3.02 & .93 & 0.00 \\
\hline Global competence & & & \\
\hline 7. Have self-defense skills like shooting and martial art. & & & \\
\hline
\end{tabular}

The experts thought that these deleted qualifications less affected teaching English.

"It depends on where the teachers teach." (Expert 10)

"It is crucial in some areas." (Expert 23)

"It rarely affects English language learning management." (Expert 34)

"Without this characteristic, English language learning management can be carried out." (Expert 34)

"Individuals have the freedom of religion rights." (Expert 34) 


\section{Quantitative Phase 2: Delphi Round 3}

12 qualifications needed reassessment were sent back to the same 48 experts participated in Delphi Round 2. The reassessed qualifications (shown in Table 12) included: 1) have skills in translation, being an interpreter, a tour guide and a master of ceremony; 2) have knowledge and understanding about Boy Scout subject to enhance collaborative skill and problem solving skill; 3) be able to identify advantages, disadvantages of each technological device as well as implement it appropriately; 4) have knowledge about southern Thai dialects and be able to use them; 5) 5ave knowledge about disasters, coping strategies and survival skills in the disasters; 6) dress expressing southern identity; 7) speak frankly; 8) love companions; 9) be graceful. Be handsome or beautiful; 10) be interested in being a national role model in teaching English; 11) be interested in making network with teachers in neighboring countries like Malaysia and Singapore; and 12) be able to do ordinary work at schools like changing light bulbs and planting trees. It was found that 6 qualifications were deleted while other 6 were kept (see Table 12). All 6 deleted qualifications were discussed below.

Table 12

Descriptive statistics of the reassessed qualifications

\begin{tabular}{|c|c|c|c|c|}
\hline Qualifications & Mean & S.D. & IQR & Interpretation \\
\hline \multicolumn{5}{|l|}{ Language proficiency } \\
\hline $\begin{array}{l}\text { 1. Have skills in translation, being an interpreter, a tour guide and a } \\
\text { master of ceremony. }\end{array}$ & 3.60 & .79 & 1.00 & kept \\
\hline \multicolumn{5}{|l|}{ Professional content knowledge } \\
\hline $\begin{array}{l}\text { 2. Have knowledge and understanding about Boy Scout subject to } \\
\text { enhance collaborative skill and problem solving skill. }\end{array}$ & 3.31 & 1.22 & 1.00 & deleted \\
\hline \multicolumn{5}{|l|}{ Technological competence } \\
\hline $\begin{array}{l}\text { 3. Be able to identify advantages, disadvantages of each } \\
\text { technological device as well as implement it appropriately. }\end{array}$ & 4.14 & .74 & 1.00 & kept \\
\hline \multicolumn{5}{|l|}{ Contextual competence } \\
\hline $\begin{array}{l}\text { 4. Have knowledge about southern Thai dialects and be able to use } \\
\text { them. }\end{array}$ & 3.31 & 1.13 & 1.00 & deleted \\
\hline $\begin{array}{l}\text { 5. Have knowledge about disasters, coping strategies and survival } \\
\text { skills in the disasters. }\end{array}$ & 3.50 & 1.07 & 1.00 & kept \\
\hline \multicolumn{5}{|l|}{ Personalities } \\
\hline 6. Dress expressing southern identity. & 3.43 & 1.00 & 1.00 & deleted \\
\hline 7. Speak frankly. & 3.52 & .85 & 1.00 & kept \\
\hline 8. Love companions. & 2.83 & 1.32 & 1.00 & deleted \\
\hline 9. Be graceful. Be handsome or beautiful. & 3.39 & 1.18 & 1.00 & deleted \\
\hline \multicolumn{5}{|l|}{ Professionalism } \\
\hline 10. Be interested in being a national role model in teaching English. & 4.16 & .88 & 1.00 & kept \\
\hline $\begin{array}{l}\text { 11. Be interested in making network with teachers in neighboring } \\
\text { countries like Malaysia and Singapore. }\end{array}$ & 4.33 & .72 & 1.00 & kept \\
\hline \multicolumn{5}{|l|}{ School duties } \\
\hline $\begin{array}{l}\text { 12. Be able to do ordinary work at schools like changing light bulbs } \\
\text { and planting trees. }\end{array}$ & 3.43 & 1.30 & 1.00 & deleted \\
\hline
\end{tabular}

The first qualification was having knowledge and understanding about Boy Scout subject to enhance collaborative skill and problem solving skill. Some Boy Scout skills were considered as irrelevant to English skills and collaborative skill could be promoted through English language learning management activities: 
"Some skills of Boy Scout, such as knotting, are irrelevant to 4 English language skills." (Expert 7)

"Teachers can carry out group work in English language learning management to enhance collaborative skill and responsibilities." (Expert 34)

The second qualification was having knowledge about southern dialects and be able to use the southern dialects. From the experts' notions, English teachers did not have to speak the southern dialects but the teacher should integrate them into English lessons.

"It is unnecessary but contains cultural issues that can be integrated into

English language teaching. This can make English lessons more interesting and increase learners' motivation in learning English." (Expert 36)

"Teachers always use central Thai dialect in learning management."(Expert 27)

"It is not necessary for English teachers to speak southern dialects." (Expert 29)

The third qualification was dressing expressing southern identity. Modest dressing and cultural relation were considered more important than expressing southern identity.

"Teachers should dress modestly and do not need to express southern

identity." (Expert 19)

"It contains cultural issues that can be integrated into English language teaching" (Expert 36)

The fourth qualification was to love companions. This qualification could bring about dishonest behaviors, especially corruption.

"It can lead to corruption." (Expert 23)

The fifth qualification was being graceful, handsome or beautiful. These physical appearances were viewed as less important that teachers' teaching abilities, dedication, good dressing, manners and behaviors.

"It is less important than teaching abilities and dedication in teaching."(Expert 20)

"Having beautiful mind is more important than having beautiful physical appearances." (Experts 2 and 36)

"Teachers should have good personalities. It is not necessary to be handsome or beautiful." (Experts 3, 14, 19, 25 and 34)

"Being handsome or beautiful is genetically transferred. Teachers should put the emphasis on appropriate personalities and dressing, good manners and behaviors." (Expert 27)

The last qualification was being able to do ordinary work at schools like changing light bulbs and planting trees. Two contradicted reasons were mentioned, including it was not teachers' responsibilities and it was the responsibilities of every teacher.

"It is the general responsibilities of janitors." (Expert 34)

"It is necessary for teachers of any subjects." (Experts 3 and 23)

\section{CONCLUSION}

To summarize, English teachers in the South of Thailand should be those who have advanced-level of English proficiency with profound knowledge of English vocabulary, grammar and linguistics, are well-equipped with knowledge related to teaching profession, professionally manage English language learning to suit the needs of learners, parents and communities with the integration of localized contents through 
various digital technological support, demonstrate teachers' spirituality, morality and ethics with good personalities, and become well-rounded educators with continuing professional development.

\section{SUGGESTIONS}

The questionnaire that has been developed from this present study derived from groups of experts. So, for further studies, the researcher should confirm the reliability of the questionnaire by administering the questionnaire to a higher number of stakeholders in the South of Thailand. Besides, the researcher should collect data from other regions of Thailand which are different from each other in terms of societies, cultures, economy, and religions.

\section{REFERENCES}

Anantapool, W., Keeratikorntanayod, W., \& Chobphon, P. (2018). Developing English Proficiency Standards for EnglLanguage Teachers in Thailand. Humanities Journal, 35 (2), $1-34$.

Barnes, B. D. and Lock, G. (2013). Student Perceptions of Effective Foreign Language Teachers: A Quantitative Investigation from a Korean University. Australian Journal of Teacher Education, 38(2), Retrieved from http://ro.ecu.edu.au/ajte/vol38/iss2/2

Brosh, H. (1996). Perceived characteristics of the effective language teacher. Foreign Language Annuals, 29(2), 125-138.

Brown, H. D. (2001). Teaching by principles: An interactive approach to language pedagogy (2nd ed.). Longman.

Cates, K. A. (2002). Teaching for a Better World: Global Issues and Language Education. Human Rights Education in Asian Schools, 5, 41-52.

Celik, S., Arikan, A., \& Cener, M. (2013). In the Eyes of Turkish EFL Learners: What Makes an Effective Foreign Language Teacher?. Porta Linguarum, 20, 287-297.

Chea, P. (2014). Proposed Guidelines for Developing Primary English Teacher Training Programs for Provincial Teacher Training Colleges. Kingdom of Cambodia. OJED, 9(1), 487-491.

Creswell, J. W., \& Plano Clark, V. L. (2011). Designing and conducting mixed methods research (2nd ed.). Thousand Oaks, CA: Sage Publications, Inc.

Dincer, A., Goksu, A., Takkac, A., Yazici, M. (2013). Common Characteristics of an Effective English Language Teacher. The International Journal of Educational Researchers, 4(3), 1-8.

Demriroz, H., \& Yesilyurt, S. (2015). Effective Foreign Language Teaching: Perceptions of Prospective English Language Teachers. Universal Journal of Educational Research, 3(11), 862-870. Doi: 10.13189/ujer.2015.031112

Doro, K. \& T. Balla, A. (2014). Beliefs about the effective language teacher: the challenges of training (future) English teachers. In B. Fregan (Ed.). Success and Challenges in Foreign Language Teaching (pp. 49-54). Budapest: Nemzeti Kozszolgalati Egyetem.

Education First. (2019). English First English Proficiency Index (EF EPI). Retrieved 4 February, 2019 from: https://www.ef.co.th/epi/regions/asia/thailand/ 
Fareh, S. (2010). Challenges of Teaching English in the Arab World: Why Can't EFL Programs deliver as expected? Procedia Social \& Behavioral Sciences, 2, 3600-3604.

Fong, S. F., Ch'ngb, P. E., Por, F. P. (2013). Development of ICT Competency Standard Using the Delphi Technique. Social and Behavioral Sciences, 103, 299-314.

Franz, J. \& Teo, A. (2017). 'A 2 is Normal' - Thai Secondary English Teachers' Encounters with CEFR. RELC Journal, 1-17.

Ghasemi, B., \& Hashemi, M. (2011). The Study of the Characteristics of Successful English Language Teachers from the Viewpoint of the English Language Students of Islamic Azad University, Hamedan Branch. Procedia Social and Behavioral Sciences, 28, 411-415. Doi:10.1016/j.sbspro.2011.11.078

Gilakjani, A. P. (2017). A Review of the Literature on the Integration of Technology into the Learning and Teaching of English Language Skills. International Journal of English Linguistics, 7(5), 95-106.

Green, R. A. (2014). The Delphi Technique in Educational Research. SAGE Open, 1-8.

Greene, J. C., Caracelli, V. J., \& Graham, W. F. (1989). "Toward a Conceptual Framework for Mixed-method Evaluation Designs". Educational Evaluation and Policy Analysis, 11(3), 255-274.

Hadi, A. (2019). Exploring preparation of pre-service teachers' English proficiency and pedagogy: Stories from an EFL teacher education program. The Qualitative Report, 24(8), 1946-1966. Retrieved from https://nsuworks.nova.edu/tqr/vol24/iss8/9

Hien, D.T. (2019). Teacher characteristics: what do EFL preservice teachers expect? Journal of Foreign Studies, 35(6), 90-105.

Izadinia, M. (2012).Teacher educators as Role Models: A qualitative examination of student teachers' and teacher educators' views towards their roles. The Qualitative Report, 17, 1-15.

Jing, H. (2013). Global awareness: Foreign language teachers' beliefs and practices. Intercultural Communication Studies, 12(1), 95-116.

Kaewwichian, D. and Jaturapitakkul, N. (2018). Self-perception of English Proficiency of Thai Lower Secondary FL Teachers. rEFLections, 25(2), 21-41.

Khan, I. A. (2011). The Teacher of English: Pedogogic Relevance in Saudi Arabia. English language Teaching, 4(2), 112-120.

Linstone, H. A., \& Turoff, M. (1975). Introduction. In H. A. Linstone, \& M. Turoff (Eds.). The Delphi method: Techniques and applications (pp. 3-12). Reading, MA: Addison-Wesley Publishing Company.

Linstone, H. A., \& Turoff, M. (2002). "The Delphi Method: Techniques and Applications". Retrieved 8 June, 2014 from: http://is.njit.edu/pubs/delphibook/delphibook.pdf

Mahmoud, A., \& Thabet, A. (2012). The Qualities of the Good English Teacher as Perceived by Saudi and Yemeni College of Students of English. Greener Journal of Educational Research, 3(2), 72-79.

Mayahi, N., \& Mayahi, F. (2014). “Isn't it our fault?” Teachers Language Knowledge and Skills. Procedia-Social and Behavioral Sciences, 98, 1119-1127.

Medgyes, P. (1994). The non-native teachers. London: MacMillan. 
Ministry of Education. (2009). Thai Qualifications Framework for Higher Education (TQF: HE). Bangkok: Ministry of Education.

Ministry of Education. (2011). Standard of Qualification and Specification for Bachelor of Education (Five-year course). Bangkok: Ministry of Education.

Ministry of Education. (2019). Standard of Qualification and Specification for Bachelor of Education (Four-year course). Bangkok: Ministry of Education.

Mishra, P., \& Koehler, M. J. (2006). Technological pedagogical content knowledge: A framework for integrating technology in teachers' knowledge. Teachers College Record, 108(6), 1017-1054.

Moonsrakoo, Y., Patthiyathinee, S. \& Ponyiem, R. (2015). Development of Indicators for English Teachers'Competency in Roi-Et Province Primary Educational Service Area Office. Faculty of Education, Mahasarakram University Journal, 21(2), 250-265.

Muir, C., Dörnyei, Z. \& Adolphs, S. (2019). Role Models in Language Learning: Results of a Large-Scale International Survey. Applied Linguistics, 1-24.

Ozkan, Y. \& Mutlu, A. K. (2017). Pre-service English Teachers Views of the Effective Teacher and Teaching. Mediterranean Journal of Humanities, 7(1), 213-231.

Park, G., \& Lee, H. (2006). Characteristics of Effective Teachers Perceived by High School Teachers and Students in Korea. Asia Pacific Education Review, 7(2), 236-248.

Promsaka Na Sakolnakorn, T., Churngchaw C., Laeheem, K. (2019). Development of English Learning in Three Southern Border Provinces. Thailand Research Fund (TRF).

Renandya, W. A. (2018). What kind of English proficiency is needed for effective teaching? [Presentation]. Invited paper presented in the Indonesian TESOL Summit, 3-4 Feb 2018, Century Park Hotel, Jakarta.

Richards, J. C. (2001). Curriculum Development in Language Teaching. New York: Cambridge University Press.

Richards, J. C. (2013). Curriculum Approaches in Language Teaching: Forward, Central, and Backward Design. RELC Journal, 44(1), 5-33.

Savu, E., Chirimbu, S. \& Dejica-Carțiș, A. (2014). What skills do foreign languages teachers need in the 21st century? Professional Communication and Translation Studies, 7(1- 2), 151-158.

Shahzada, G. (2012). Views of the Teachers Regarding the Students'Poor Pronunciation in English Language. Journal of Educational and Social Research, 2(1), 309-316.

Shishavan, H.B. \& Sadeghi, K. (2009). Characteristics of an Effective English Language Teacher as Perceived by Iranian Teachers and Learners of English. English Language Teaching Journal, 2(4), 130-143.

Shulman, L. (1987). Knowledge and teaching: Foundations of the new reform. Harvard Educational Review, 57(1), 1-22.

Songsirisak, P. (2017). Non-native English speaking teachers: Uncovering Thai EFL teahers' instructional practices in an International program of Thai university. Journal of Education, Mahasarakham University, 11(4), 125-138.

Sriprom, C., Rungswang, A., Sukwitthayakul, C. \& Chansri, N. (2019). Personality Traits of Thai Gen Z Undergraduates: Challenges in the EFL Classroom? PASAA, 57, 65-190. 
Teachers Council of Thailand. (2013). Regulations of Professional Standard 2013, 19 September.

Tangcharaen, W., Thomas, S. S., Mando, A. D. \& Suktakulvej, S. (2016). Being as Teacher. St. Theresa Journal of Humanities and Social Sciences, 2(1), 74-88.

Teachers Council of Thailand. (2013). Regulations of Professional Standard 2013, 19 September.

Thanaphatchottiwat, S. \& Parnichparinchai, T. (2015). Professional Development of Student Teachers in Higher Education Institutions Based on the Application of Hybridity Theory and Third Space Concept. Journal of Graduate Studies in Northern Rajabhat Universities, 5(9), $1-10$.

Virgiyanti, D. F., Widiati, U \& Suharmanto, S. (2016). Characteristics of Effective Junior High School English Teachers in Kabupaten Pacitan Based on Students' and Teachers' Perceptions. Journal Pendidikan: Teori, Penelitian, dan Pengembangan, 1(3), 338-346.

Walker, J. (2011). Being professional in English language teaching services: a Delphi panel study. Quality Assurance In Education, 9(4), 307-334.

Wattanatorn, A. (2013). Teacher Education and Change for Human and Social Growth. Journal of Education Naresuan University, 15(1), 111-116.

Watson Todd, R. (2016). English proficiency standards in Thai universities. Address at the Assumption University Annual Faculty Seminar, 2016.

Wichadee, S. (2010). Defining the effective English language teacher: Students' and teachers' perspectives. In Stoke, A.M (Ed.), JALT2009 Conference Proceedings. Tokyo: JALT.

Wichadee, S., \& Orawiwatnakul, W. (2012). Characteristics of effective language teachers as perceived by low and high proficiency students. European Journal of Social Sciences, $31(3), 425-438$.

Wiggins, G., \& McTighe, J. (2006). Understanding by Design: A Framework for Effecting Curricular Development and Assessment. Alexandria, VA. Association for Supervision and Curriculum Development.

Yasmin, F. \& Islam, M. (2018). Academic Roles of English Language Teachers: A Study of the Perceptions of Pakistani Teachers and Students. Journal of Foreign Languages, Cultures and Civilizations, 6(1), 13-24.

Yoothong, J. (2004). Locality in the South of Thailand: Civil Politics. Thaksinkadee, 7(1), 11-61.

Zamani, R. \& Ahangari, S. (2016). Characteristics of an Effective English LanguageTeacher (EELT) as Percieved by Learners of English. International Journal of Foreign language Teaching \& Research, 4(14), 69-88. 